\title{
Zastosowanie wskaźnika TAI (thermal alteration index) i analizy palinofacjalnej do określenia stopnia dojrzałości termicznej materii organicznej w utworach górnego permu i triasu w północnej części niecki nidziańskiej (Polska centralna)
}

\author{
Application of the TAI (Thermal Alteration Index) and palynofacial analysis for determining \\ the degree of organic matter termal maturity in the Upper Permian and Triassic deposits \\ in the northern part of the Nida Basin (central Poland)
}

\author{
Anna Fijałkowska-Mader
}

Państwowy Instytut Geologiczny - Państwowy Instytut Badawczy, Oddział Świętokrzyski

\begin{abstract}
STRESZCZENIE: Określanie dojrzałości termicznej palinomorf na podstawie ich barwy jest metodą powszechnie stosowaną w prospekcji węglowodorów. Kolor zewnętrznej błony miospor zmienia się na skutek podgrzania od bladożółtego po czarny w zależności od paleotemperatury. Obecnie funkcjonuje wiele skal barw palinomorf skorelowanych z wartościami refleksyjności witrynitu, maksymalną temperaturą pogrzebania i stadiami generacji węglowodorów. Ze względu na zróżnicowany zarówno pod względem taksonomicznym, jak i morfologicznym materiał autorka posłużyła się skalą TAI AMOCO. Przeanalizowano ponadto udział poszczególnych grup kerogenu w palinofacjach pod kątem ich węglowodorowego potencjału. Badaniami objęto osady górnego permu i triasu z 11 otworów wiertniczych zlokalizowanych w północnej części niecki nidziańskiej. Wykazały one, że w próbkach triasowych oraz w próbkach górnego permu z otworu Milianów IG 1 dominuje jasnożółty do pomarańczowego kolor spor i ziaren pyłku, odpowiadający indeksowi TAI od 1 do 4, czyli stadium przed generacją ropy naftowej i stadium wczesnej generacji ropy naftowej. Jedynie w próbach górnego permu z otworu Pągów IG 1 dominuje brązowy kolor miospor, który odpowiada indeksowi TAI od 4+ do 5, czyli głównemu stadium generacji ropy naftowej. Dominująca wartość refleksyjność witrynitu $R_{o}$ wynosi $0,4-0,6 \%$, a zatem stopień dojrzałości materii organicznej w utworach górnego permu i triasu jest niezbyt wysoki, co świadczy o stosunkowo niskich temperaturach diagenezy osadu $\left(<80^{\circ} \mathrm{C}\right)$. Z analizy palinofacji wynika, że w utworach górnego permu i triasu występuje kerogen mieszany i strukturalny. Kerogen mieszany, stwierdzony w skałach węglanowych, zawiera amorficzny kerogen drobnorozproszony i ,fluffy" pochodzenia glonowego oraz kerogen strukturalny, pochodzenia terygenicznego, głównie egzynit i witrynit. Kerogen mieszany charakteryzuje się potencjałem ropnym (kerogen ropotwórczy), natomiast kerogen strukturalny - potencjałem ropno-gazowym.
\end{abstract}

Słowa kluczowe: wskaźnik TAI, palinofacja, kerogen, górny perm, trias, niecka nidziańska.

ABSTRACT: Determining the thermal maturity of palynomorph based on their color is a method commonly used in hydrocarbon prospecting. The color of the outer membrane of miospores (exine) changes as a result of heating from pale yellow to black depending on the paleotemperature. Currently, there are many palynomorph color scales correlated with the value of vitrinite reflectance, temperature of burial and hydrocarbon generation stages. Due to the varied material, both in taxonomic and morphological terms, the author used the TAI AMOCO scale. Furthermore, the share of individual kerogen groups in palynofacies was analyzed in terms of their hydrocarbon potential. The Upper Permian and Triassic deposits from eleven boreholes located in the north part of the Nida Basin were investigated. They showed that the Triassic and in the Upper Permian samples from the Milianów IG 1 borehole, are dominated by the pale yellow to orange color of spores and pollen grains, corresponding to a TAI index from 1 to 4, i.e. the pre-generation, dry gas and the early oil generation windows. In turn, only the samples of the Upper Permian from the Pągów IG 1 borehole are dominated by the brown color of miospores, which corresponds to a TAI index from $4+$ to 5 , i.e. the peak oil prone. Dominant vitrinite reflectance $R_{o}$ varies from $0,4 \%$ to $0,6 \%$, so the degree of organic matter maturity in the Upper Permian and Triassic deposits is not very high, which indicates relatively low temperatures of sediment diagenesis $\left(<80^{\circ} \mathrm{C}\right)$. Analysis of palynofacies showed that the Upper Permian and Triassic deposits contain mixed and structural kerogen. Mixed kerogen, occurring in carbonate rocks, contains amorphous fine-scattered kerogen and "fluffy"

Autor do korespondencji: A. Fijałkowska-Mader, e-mail: anna.mader@pgi.gov.pl

Artykuł nadesłano do Redakcji: 19.03.2020 r. Zatwierdzono do druku: 16.07.2020 r. 
of algae origin, as well as structural kerogen of terrigeneous origin, mainly exinite and vitrinite. Mixed kerogen is characterized by oil potential, whereas structural kerogen - by gas-oil potential.

Key words: TAI, palynofacies, kerogen, Upper Permian, Triassic, Nida Basin.

\section{Wprowadzenie}

Niniejszy artykuł stanowi kontynuację badań nad występowaniem węglowodorów w utworach permu i triasu północnej części niecki nidziańskiej, zapoczątkowanych przez Kuletę $\mathrm{i}$ in. (2000), przy zastosowaniu metody TAI (thermal alteration index) - wskaźnika uwarunkowanego metamorfizmem materii organicznej wchodzącej w skład zewnętrznej błony - egzyny palinomorf: spor, ziaren pyłku i glonów (Staplin, 1969). Dotychczas metoda ta, oparta głównie na akritarchach, była stosowana z powodzeniem do skał paleozoiku (z wyłączeniem permu) na obszarze Gór Świętokrzyskich i niecki nidziańskiej (Szczepanik, 1997, 2007, 2008, 2018, 2019; Szczepanik i Malec, 2001). Jej wyniki były porównywalne z otrzymanymi przy zastosowaniu metody CAI (conodont alteration index) i średniej refleksyjności witrynitu $\left(R_{o}\right)$ (Grotek, 2000, $2008,2019)$. Celem przeprowadzonych przez autorkę badań była analiza barwy spor i ziaren pyłku w osadach górnego permu i triasu pod kątem ich dojrzałości termicznej oraz analiza palinofacjalna i określenie typów kerogenu w potencjalnych skałach macierzystych.

Niecka nidziańska, zwana też miechowską, stanowi południowe zakończenie bruzdy środkowopolskiej - strefy o największej subsydencji i miąższości osadów w permsko-triasowym basenie sedymentacyjnym, przekraczającej $3 \mathrm{~km}$ (Dadlez et al., 1998). Region ten jest silnie zaangażowany tektonicznie. Znajduje się tu przedłużenie strefy tektonicznej Tomaszów-Grójec, która miała znaczący wpływ na rozkład facji i miąższości w permie i triasie. Od północy przylega do niej uskok Gomunic, a od południowego wschodu - uskok Pilicy (Jurkiewicz, 1975; Morawska, 1986; Dadlez i Marek, 1996).

\section{Material i metody badawcze}

Materiał do badań pochodził z rdzeni jedenastu otworów wiertniczych zlokalizowanych w północnej części niecki nidziańskiej: Biała Wielka IG 1, Boża Wola IG 1, Gidle-2, Gomunice-12, Gomunice-13, Gomunice-15, Milianów IG 1, Pągów IG 1, Węgleszyn IG 1, Włoszczowa IG 1 i Zamoście-1 (rys. 1). Próbki pobierano z margli i wapieni dolnego cechsztynu, retu i wapienia muszlowego (facje morskie), dolomitów i margli z siarczanami oraz anhydrytów cechsztynu, retu, wapienia muszlowego i kajpru (facje sebhy i playi) oraz iłowców, mułowców, rzadziej piaskowców pstrego piaskowca i kajpru (facje lądowe: rzeczne i jeziorne). Przeanalizowano łącznie 168 próbek.

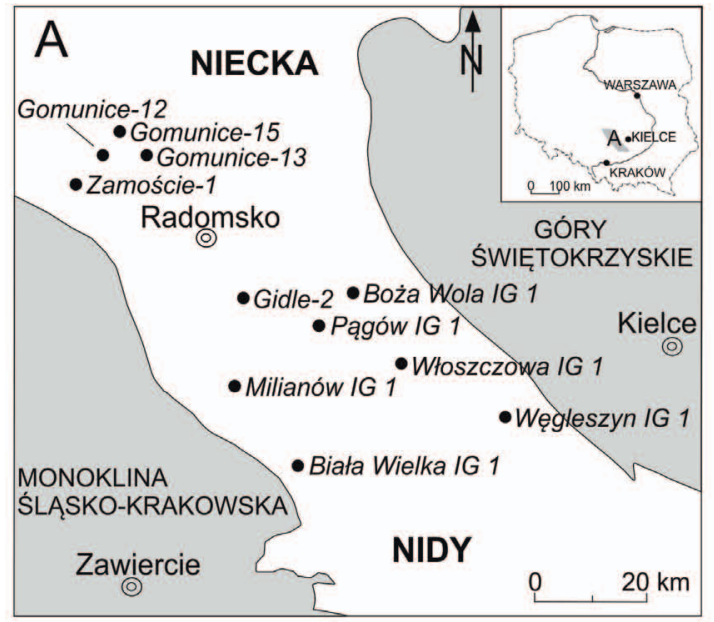

Rys. 1. Lokalizacja badanych otworów wiertniczych w północnej części niecki nidziańskiej

Fig. 1. Location of the studied boreholes in the northern part of the Nida Basin

Ze względu na różnorodny materiał palinologiczny, obejmujący zarówno spory, jak i ziarna pyłku o zróżnicowanej grubości zewnętrznej błony - egzyny i jej ornamentacji, zastosowano metodę TAI.

Metoda TAI polega na porównywaniu koloru palinomorf z wzorcową skalą barw, odpowiadających różnym stadiom generacji węglowodorów. Nie istnieje jedna, standardowa, ogólnie akceptowana skala kolorystyczna. Różni badacze w ciągu ostatnich lat przyjmowali nieco inne skale wzorcowe i inaczej interpretowali stopień dojrzałości termicznej (por. Waksmundzka, 1995). Wynika to z faktu złożoności procesów uwęglania materii organicznej i wpływu na stopień dojrzałości materii organicznej czynników innych niż temperatura, takich jak: typ substancji organicznej (kerogenu), czas oddziaływania, ciśnienie czy zawartość wody w osadzie. Podstawowym czynnikiem decydującym o barwie uzyskanych palinomorf, oprócz struktury i grubości egzyny, pozostaje maksymalna temperatura $\left(T_{\max }\right)$ osiągnięta przez skały na skutek pogrzebania (Marshall, 1990; Szczepanik, 2007, 2018). Autorka przyjęła za wzorcową skalę TAI AMOCO, zmodyfikowaną przez Engelhardta et al. (1992) (por. Szczepanik i Malec, 2001; Szczepanik, 2008), w której wyróżnia się sześć podstawowych przedziałów kolorystycznych, odpowiadających poszczególnym stadiom - od materii niedojrzałej poprzez stadia wczesnej i późnej generacji ropy 
naftowej, kondensatu oraz gazowe po stadium materii ,przejrzałej" (over mature). Ponadto odniesiono otrzymane wskaźniki TAI do wartości refleksyjności witrynitu $\left(R_{o}\right)$ na podstawie prac Narkiewicz i Nehring-Lefeld (1993), Waksmundzkiej (1995) oraz Bielenia i Matyasik (2018).

Definicję palinofacji jako materii organicznej otrzymanej w wyniku standardowej maceracji palinologicznej przy użyciu kwasów solnego i fluorowodorowego ze skał osadowych autorka przyjęła za Tysonem (1995). Materię organiczną (kerogen) sklasyfikowano zgodnie z Amsterdam Palynological Organic Matter Classification '91 (Traverse, 1994), gdzie została ona podzielona na palinomorfy, materię strukturalną i materię niestrukturalną. Wśród palinomorf wyróżniono: spory, ziarna pyłku, glony (akritarchy, prazynofity, glony słodkowodne, dinocysty), chitinozoa, zoomorfy i spory grzybów. Materia strukturalna obejmuje: drewno, czyli wiązki przewodzące, nabłonki (epidermy i kutikule), szczątki zwierząt i fragmenty grzybni oraz materię strukturalną nieoznaczalną. W obrębie materii niestrukturalnej wyróżniono: cząstki homogeniczne, cząstki heterogeniczne, cząstki „fluffy” - o gąbczastej, prześwitującej strukturze i nieregularnych kształtach oraz cząstki drobnorozproszone. Cząstki heterogeniczne są wskaźnikiem lądowego pochodzenia materii organicznej (Tyson, 1995), natomiast cząstki „fluffy”, o genezie planktonicznej lub/i bakteryjnej (Batten, 1996), wskazują na środowisko morskie (Tyson, 1995).

Na podstawie prac autorów: Batten (1982), Sharifi et al. (2018) i Deaf et al. (2020) przeanalizowano udział poszczególnych grup kerogenu w palinofacjach pod kątem ich węglowodorowego potencjału, wyróżniając:

- kerogen amorficzny (drobnorozproszony i „fluffy”) pochodzenia glonowego, charakteryzujący się potencjałem ropnym;

- kerogen strukturalny - egzynit, obejmujący spory, ziarna pyłku i nabłonki roślinne, charakteryzujący się potencjałem ropnym;

- kerogen strukturalny - alginit, obejmujący glony planktoniczne, w tym akritarchy, charakteryzujący się potencjałem ropnym;

- kerogen strukturalny - witrynit, obejmujący tkanki przewodzące określane mianem ,drewna”, charakteryzujący się potencjałem ropno-gazowym;

- kerogen strukturalny - inertynit, obejmujący utlenione, na ogół redeponowane „drewno”, który nie ma potencjału węglowodorowego.

Kerogen amorficzny i strukturalny: egzynit oraz alginit (z wyłączeniem glonów słodkowodnych) odpowiadają typowi II kerogenu według Waplesa (1985), alginit pochodzenia słodkowodnego - typowi I, witrynit - typowi III natomiast inertynit - IV typowi.
Maceracje próbek przeprowadzono przy użyciu standardowej metody fluorowodorowej opisanej przez OrłowskąZwolińską (1983). Macerat przemywano na sitach polipropylenowych o średnicy oczek $15 \mu \mathrm{m}$. W trakcie prac laboratoryjnych nie stosowano kwasu azotowego ani innych utleniaczy, które mogłyby spowodować rozjaśnienie materii organicznej i zaburzyć wyniki obserwacji. $Z$ tak otrzymanego maceratu sporządzono preparaty mikroskopowe, zatopione w araldycie (rodzaj żywicy epoksydowej), o powierzchni $240 \times 240 \mathrm{~mm}$. Kolor palinomorf określano w świetle przechodzącym. W badaniach wykorzystano współpracę mikroskopu biologicznego Laborlux S z cyfrową kamerą Canon PowerShot A620 i komputerem. W przypadku wszystkich obserwowanych i fotografowanych okazów stosowano identyczne ustawienia przesłony, położenia kondensora i intensywności oświetlenia. Dane kolorystyczne porównywano z oryginalnymi wzorcami skali TAI. Na każdym z badanych preparatów wykonywano co najmniej 20 pojedynczych analiz. Na rysunkach obrazujących wyniki badań (rys. 2-4) przedstawiono po trzy najliczniej występujące miospory w próbkach reprezentatywnych dla poszczególnych wydzieleń litostratygraficznych.

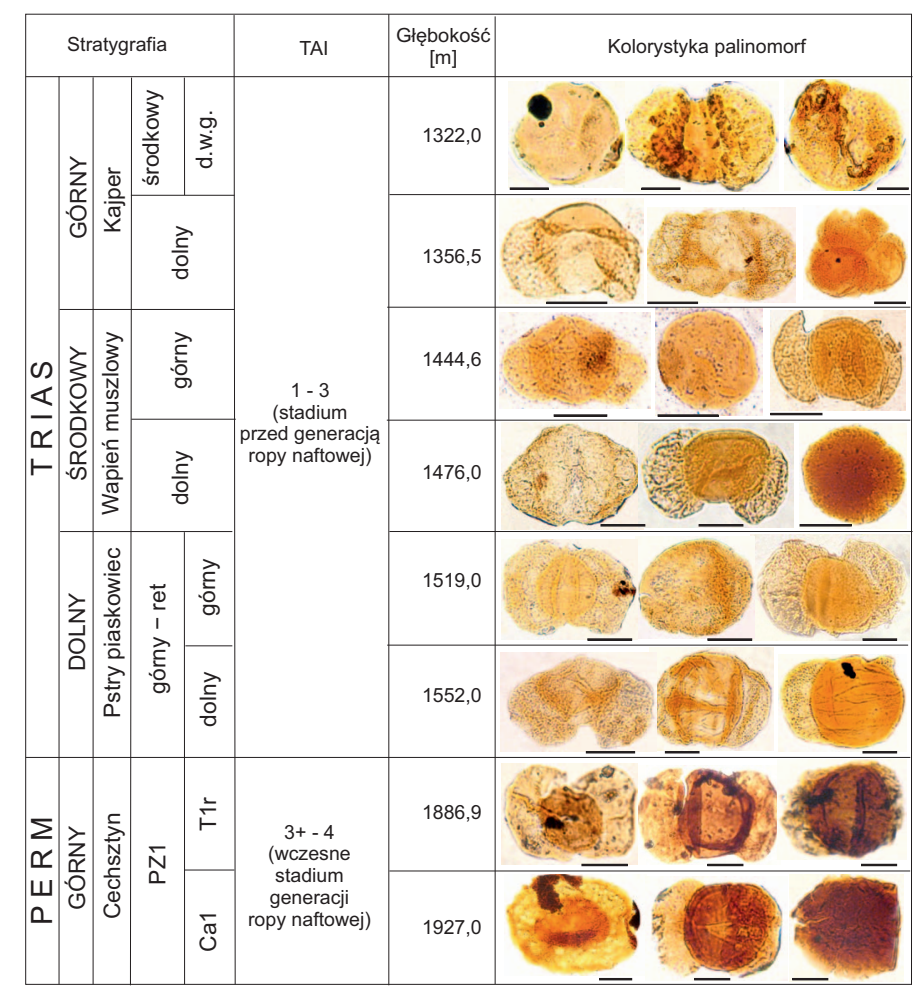

Rys. 2. Dojrzałość termiczna spor i ziaren pyłku w osadach permu i triasu z otworu Milianów IG 1. Skala liniowa $30 \mu \mathrm{m}$. Objaśnienia skrótów: d.w.g. - dolne warstwy gipsowe

Fig. 2. Thermal maturity of spores and pollen grains in the Permian and Triassic deposits from the Milianów IG 1 borehole. Scale bar $30 \mu \mathrm{m}$ 


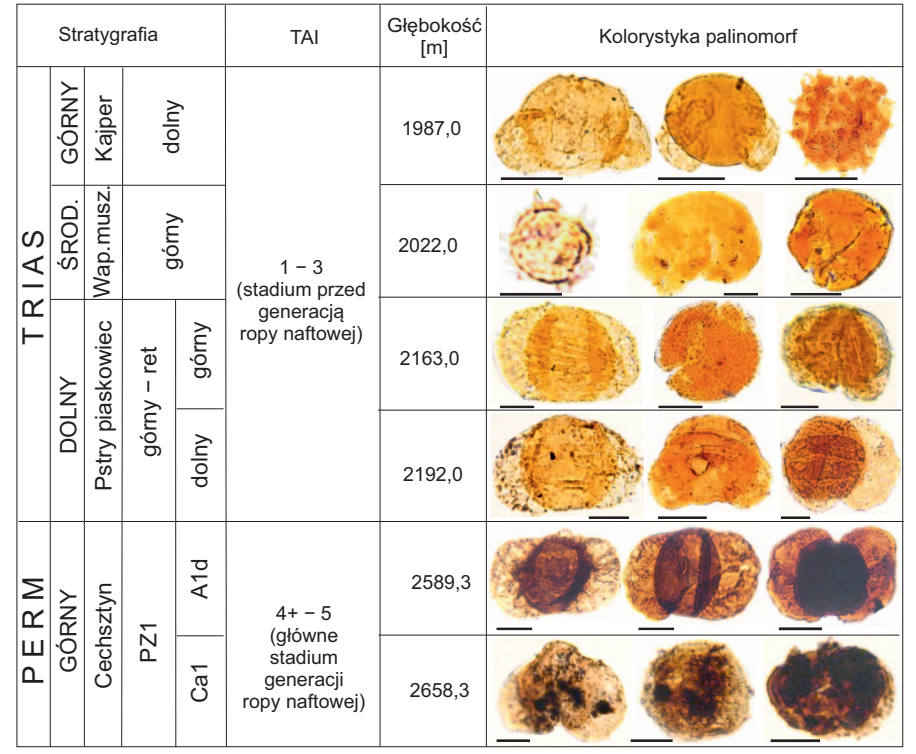

Rys. 3. Dojrzałość termiczna palinomorf w osadach permu i triasu z otworu Pągów IG 1. Skala liniowa $30 \mu \mathrm{m}$. Objaśnienia skrótów: ŚROD. - środkowy, Wap. muszl. - wapień muszlowy

Fig. 3. Thermal maturity of palynomorphs in the Permian and Triassic deposits from the Pągów IG 1 borehole. Scale bar $30 \mu \mathrm{m}$

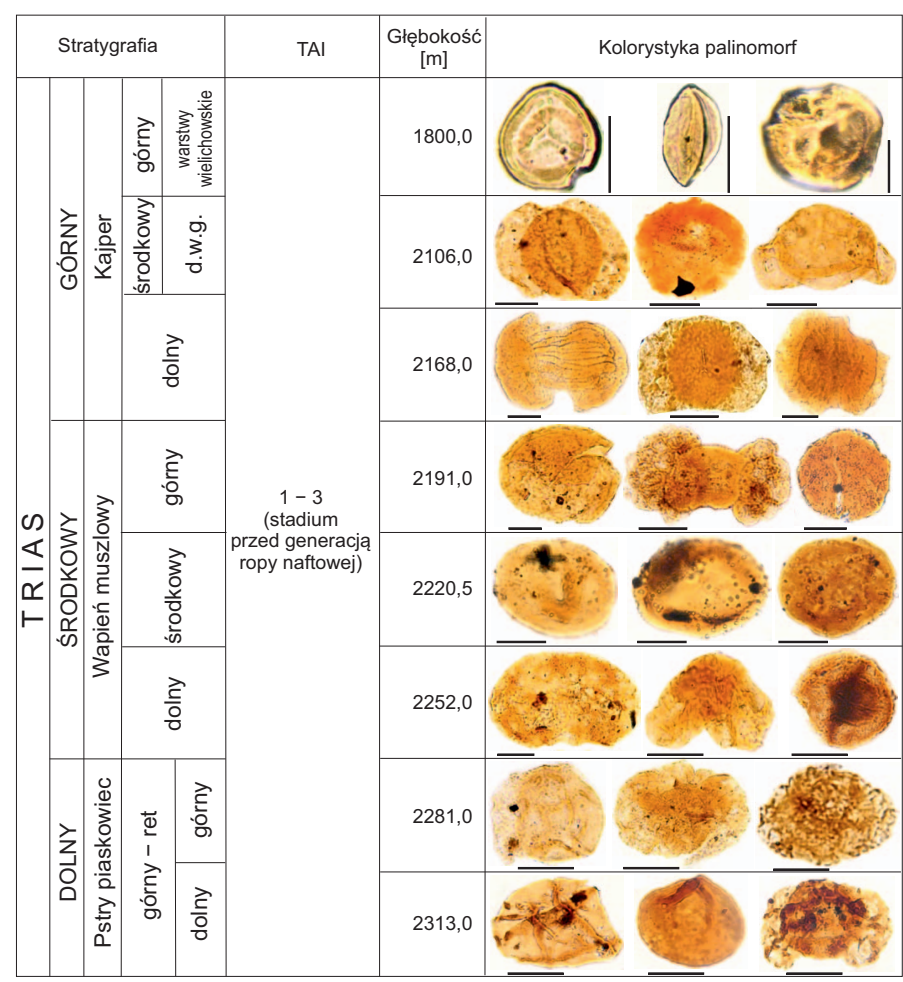

Rys. 4. Dojrzałość termiczna spor i ziaren pyłku w osadach triasu z otworu Włoszczowa IG 1. Skala liniowa $30 \mu \mathrm{m}$. Objaśnienia skrótów: d.w.g. - dolne warstwy gipsowe

Fig. 4. Thermal maturity of spores and pollen grains in the Triassic deposits from the Włoszczowa IG 1 borehole. Scale bar $30 \mu \mathrm{m}$

\section{Wyniki badań}

Z przeanalizowanych 168 próbek 91 zawierało palinomorfy. W próbkach triasowych z otworów: Biała Wielka IG 1, Gidle-2 (dolny trias), Milianów IG 1 (rys. 2), Pągów IG 1 (rys. 3), Węgleszyn IG 1, Włoszczowa IG 1 (rys. 4) i Zamoście IG 1 dominuje jasnożółty do jasnopomarańczowego kolor spor i ziaren pyłku. Odpowiada on indeksowi TAI od 1 do 3, czyli stadium niedojrzałemu, przed generacją ropy naftowej (tab. 1). Ten indeks TAI można odnieść do przedziału $0,2-0,4 \%$ w skali refleksyjności witrynitu $\left(R_{o}\right)$ (por. Utting et al., 1989; Waksmundzka, 1995; Pross et al., 2007).

W próbkach z górnego permu z otworu Milianów IG 1 (rys. 2) oraz próbkach triasowych z otworów: Boża Wola IG 1, Gidle-2 (trias środkowy i górny), Gomunice-13 i Gomunice-15 przeważa pomarańczowa barwa miospor. Odpowiada ona indeksowi TAI od 3+ do 4, czyli stadium wczesnej generacji ropy naftowej oraz $R_{o} 0,5-0,6 \%$.

W próbkach z górnego permu z otworu Pągów IG 1 (rys. 3) dominuje brązowy kolor miospor, który odpowiada indeksowi TAI od 4+ do 5, czyli głównemu stadium generacji ropy naftowej. Ten indeks TAI można odnieść do refleksyjności witrynitu $\left(R_{o}\right) 0,7-0,9 \%$.

$\mathrm{Z}$ analizy rodzajów kerogenu w palinofacjach wynika, że w utworach górnego permu i triasu występuje kerogen mieszany i strukturalny. Kerogen mieszany, stwierdzony w skałach węglanowych, zawiera amorficzny kerogen drobnorozproszony i ,fluffy" pochodzenia glonowego oraz kerogen strukturalny, pochodzenia terygenicznego, głównie egzynit i witrynit (rys. 5).

Tabela 1. Przybliżona korelacja wskaźników przeobrażenia materii organicznej ze skalami SCI (spore coloration index) i TAI AMOCO

Table 1. Generalized correlation of kerogen maturity parameters with SCI (Spore Coloration Index) and TAI AMOCO

\begin{tabular}{|c|c|c|c|c|}
\hline $\begin{array}{c}\text { Refleksyjność } \\
\text { witrynitu }\end{array}$ & $\begin{array}{l}\text { Wskaźnik } \\
\text { koloru } \\
\text { spor }\end{array}$ & \multirow[t]{2}{*}{$\begin{array}{c}\text { TAI } \\
\text { AMOCO }\end{array}$} & $T_{\max }$ & \multirow[t]{2}{*}{$\begin{array}{c}\text { Stadium } \\
\text { generacji } \\
\text { węglowodorów }\end{array}$} \\
\hline$\left[\begin{array}{ll}\% & R\end{array}\right]$ & [SCI] & & {$\left[{ }^{\circ} \mathbf{C}\right]$} & \\
\hline 0,20 & 2,0 & $1-2+$ & 400 & niedojrzałe \\
\hline 0,40 & 4,0 & 3 & 420 & niedojrzałe \\
\hline 0,50 & 5,0 & $3+$ & 430 & $\begin{array}{l}\text { wczesne stadium } \\
\text { generowania ropy }\end{array}$ \\
\hline 0,60 & 6,0 & 4 & 440 & $\begin{array}{l}\text { wczesne stadium } \\
\text { generowania ropy }\end{array}$ \\
\hline 0,70 & \multirow{2}{*}{7,4} & \multirow{2}{*}{$4+$} & \multirow{2}{*}{450} & \multirow{2}{*}{$\begin{array}{l}\text { główne stadium } \\
\text { generowania ropy }\end{array}$} \\
\hline 0,80 & & & & \\
\hline 0,90 & 7,8 & 5 & 455 & $\begin{array}{l}\text { główne stadium } \\
\text { generowania ropy }\end{array}$ \\
\hline 1,00 & 8,1 & $5+$ & 460 & $\begin{array}{l}\text { główne stadium } \\
\text { generowania ropy }\end{array}$ \\
\hline
\end{tabular}




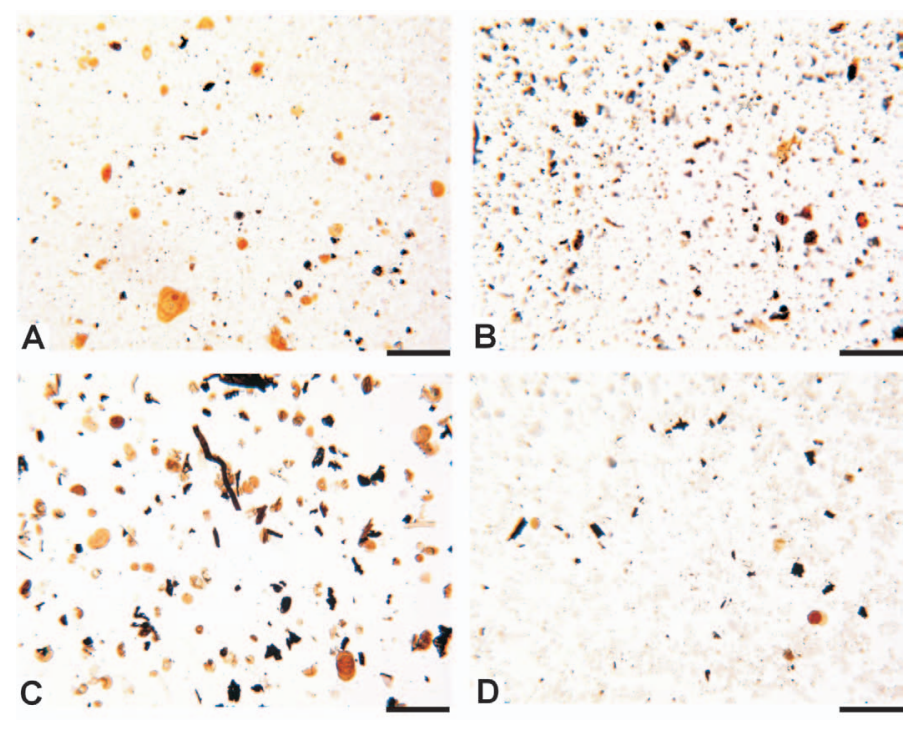

Rys. 5. Typy kerogenu występujące w analizowanych osadach triasu. A - kerogen mieszany: amorficzny drobnorozproszony pochodzenia glonowego i strukturalny egzynit o potencjale ropnym; otwór Biała Wielka IG 1, głęb. 1196,9 m; środkowy trias, górny wapień muszlowy; B - kerogen strukturalny: witrynit o potencjale gazowym; otwór Biała Wielka IG 1, głęb. 1995,0 m; dolny trias, dolny ret; $\mathrm{C}$ - kerogen strukturalny: egzynit i witrynit o potencjale ropno-gazowym; otwór Gidle-2, głęb. 1660,5 m; środkowy trias, środkowy wapień muszlowy; D - kerogen mieszany: amorficzny drobnorozproszony i ,fluffy” pochodzenia glonowego oraz strukturalny: egzynit i witrynit o potencjale ropnym; otwór Milianów IG 1, głęb. 2192,0 m; dolny trias, dolny ret. Skala liniowa $100 \mu \mathrm{m}$

Fig. 5. Kerogen types in the studied Triassic deposits. A - mixed kerogen: amorphous, fine-scattered algae material and structural exinite with oil potential; Biała Wielka IG 1 borehole, depth 1196.9 m; Middle Triassic, Upper Muschelkalk; B - structural kerogen vitrinite with gas potential; Biała Wielka IG 1 borehole, depth 1195.0 m; Lower Triassic, Lower Röt; C - structural kerogen: exinite and vitrinite with oil-gas potential; Gidle-2 borehole, depth 1660.5 m; Middle Triassic, Middle Muschelkalk; D - mixed kerogen: amorphous, fine-scattered and „fluffy” algae material as well as structural exinite and vitrinite with oil potential; Milianów IG 1, depth 2192.0 m; Lower Triassic, Lower Röt. Scale bar $100 \mu \mathrm{m}$

\section{Dyskusja}

Stopień dojrzałości materii organicznej w utworach górnego permu i triasu północnej części niecki nidziańskiej jest niezbyt wysoki. W utworach górnego permu wartość $R_{o}$ otrzymana przez autorkę $\mathrm{w}$ granicach $0,5-0,9 \%$ jest zbliżona do wartości podanych przez Grotek $(2000,2008)$, wynoszących $0,47-0,74 \%$. W przypadku triasu $R_{o}$ zmienia się w granicach $0,2-0,6 \%$ (wyniki autorki) i jest nieco niższa od wartości $0,46-1,13 \%$ podanych przez Grotek $(2000,2008)$. Takie wartości $R_{o}$ wskazują na dojrzałość materii organicznej na poziomie umożliwiającym procesy generacyjne $\mathrm{w}$ fazie przemian niskotemperaturowych (por. Wróbel et al., 2008) o stosunkowo niskich temperaturach diagenezy osadu $\left(<80^{\circ} \mathrm{C}\right)$. Aby jednoznacznie odpowiedzieć na pytanie, czy analizowane utwory są perspektywiczne dla występowania węglowodorów, należy określić wartości TOC - głównego wskaźnika potencjału węglowodorowego skały macierzystej (por. Peters et al., 2005).

\section{Podsumowanie}

Stopień dojrzałości materii organicznej w utworach górnego permu i triasu jest niezbyt wysoki i w większości analizowanych próbek odpowiada fazie przed generacją ropy naftowej lub fazie wczesnej generacji, co świadczy o stosunkowo niskich temperaturach diagenezy osadu $\left(<80^{\circ} \mathrm{C}\right)$. Stadium głównej generacji ropy naftowej stwierdzono tylko w osadach górnego permu z otworu Pągów IG 1. W celu określenia potencjału węglowodorowego tych osadów konieczne jest przeprowadzenie badań geochemicznych materii organicznej metodą Rock-Eval, w tym oznaczenie zawartości węgla organicznego - TOC.

Artykuł został opracowany na podstawie zadania badawczego nr 61.5105.1703.00.00 realizowanego przez Państwowy Instytut Geologiczny - Państwowy Instytut Badawczy w ramach działalności statutowej.

Autorka składa podziękowanie Recenzentom za istotne i cenne uwagi oraz sugestie.

\section{Literatura}

Batten D.J., 1982. Palynofacies, palaeoenvironments and petroleum. Journal of micropalaeontology, 1: 107-114.

Batten D.J., 1996. Palynofacies and palaeoenvironmental interpretations. [W:]: Jansonius J., McGregor D.C. (eds.). Palynology: principles and applications. American Association of Stratigraphic Palynologists Foundation, 3: 1011-1064.

Bieleń W., Matyasik I., 2018. Biomarkery, $\mathrm{T}_{\max }$ oraz refleksyjność witrynitu jako wskaźniki dojrzałości termicznej materii organicznej w skałach osadowych - korelacje i zakres stosowalności. Nafta-Gaz, 74: 575-583. DOI: 10.18668/NG.2018.08.02.

Dadlez R., Marek S., 1996. Ewolucja paleogeograficzna osadów mezozoicznych. [W:] Narkiewicz M. (red.). Analiza basenów sedymentacyjnych Niżu Polskiego. Basen mezozoiczny. Narodowe Archiwum Geologiczne PIG - PIB, Warszawa.

Dadlez R., Marek S., Pokorski J., 1998. Atlas paleogeograficzny epikontynentalnego permu i mezozoiku w Polsce. Wyd. PIG, Warszawa.

Deaf A.S., Tatoun S.S., Gentzis T., Carvajal-Ortiz H., Harding I.C., Marshall J.E.A., Ocubalidet S., 2020. Organic geochemical, palynofacies and petrographic analyses examining the hydrocarbon potential of the Kharita Formation (Albian) in the Matruh Basin, northwestern Egypt. Marine and Petroleum Geology, 112 article 104087. DOI: $10.1016 /$ j.marpetgeo.2019.104087.

Engelhardt D., Wood G.D., Barker G.W., 1992. AMOCO STANDARD Thermal Alteration Index. Materialy niepublikowane.

Grotek I., 2000. Zał. 27. Charakterystyka petrograficzna materii organicznej. [W:] Kuleta M., Zbroja S., Iwanow A., Kiersnowski H. (red.). Ropo- i gazonośność osadów permu i triasu w północnej części niecki nidziańskiej. Narodowe Archiwum Geologiczne $P I G-P I B$, Kielce. 
Grotek I., 2008. Charakterystyka petrograficzna oraz dojrzałość termiczna materii organicznej. [W:] Malec J. (red.). Potencjał węglowodorowy utworów paleozoiku i mezozoiku północno-zachodniego obrzeżenia Gór Świętokrzyskich. Narodowe Archiwum Geologiczne PIG - PIB, Kielce.

Grotek I., 2019. Charakterystyka petrologiczna i dojrzałość termiczna kambryjskiej materii organicznej. [W:] Szczepanik Z. (red.). Zaręby IG 1. Profile Gtębokich Otworów Wiertniczych Państwowego Instytutu Geologicznego, 155: 95-96.

Jurkiewicz H., 1975. Budowa geologiczna podłoża mezozoiku centralnej części niecki miechowskiej. Biuletyn Instytutu Geologicznego, 283: 5-100.

Kuleta M., Zbroja S., Iwanow A., Kiersnowski H. (red.), 2000. Ropoi gazonośność osadów permu i triasu w północnej części niecki nidziańskiej. Narodowe Archiwum Geologiczne PIG-PIB, Kielce.

Marshall J.E.A., 1990. Determination of thermal maturity. [W:] Briggs D.E., Crowther P.R. (eds.). Palaeobiology - a synthesis. Blackwell Scientific Publication, Oxford: 511-515.

Morawska A., 1986. Paleotektoniczny i paleogeograficzny rozwój północnej części niecki miechowskiej w permie. Studia Geologica Polonica, 86: 7-55.

Narkiewicz K., Nehring-Lefeld M., 1993. Zastosowanie wskaźników CAI w analizie basenów sedymentacyjnych. Przegląd Geologiczny, 41: 757-763.

Orłowska-Zwolińska T., 1983. Palinostratygrafia epikontynentalnych osadów wyższego triasu w Polsce. Prace Instytutu Geologicznego, 104: $1-89$.

Peters K.E., Walters C., Moldowan J.M., 2005. The Biomarker Guide. Vol. 2. Cambridge University Press, Cambridge.

Pross J., Pletsch T., Shillington D.J., Ligouis B., Schellenberg F., Kus J., 2007. Thermal alteration of terrestrial palynomorphs in mid-Cretaceous organic-rich mudstones intruded by an igneous sill (Newfoundland Margin, ODP Hole 1276A0). International Journal of Coal Geology, 70: 277-291.

Sharifi M., Ghasemi-Nejad E., Sarfi M., Yazdi-Moghadam M., Tarjani Salehani M., Akhtari M., 2018. Marine palynology and environmental interpretation of the Lower Cretaceous (Barremian?Aptian) rock units in the Koppeh-Dagh Basin, NE Iran. Geological Quarterly, 62: 90-99.

Staplin F.L., 1969. Sedimentary organic matter, organic metamorphism and oil and gas occurrence. Bulletin of Canadian Petroleum Geology, 17: 47-66.

Szczepanik Z., 1997. Preliminary results of thermal alteration investigations of the Cambrian acritarchs in the Holy Cross Mts. Geological Quarterly, 41: 251-264.

Szczepanik Z., 2007. Regionalny gradient paleotermiczny w zapisie palinologicznym starszego paleozoiku i dewonu Gór Świętokrzyskich. [W:] Żylińska A. (red.). Granice paleontologii.
20 Konferencja Naukowa Paleobiologów i Biostratygrafów PTG, Św. Katarzyna pod Łysica, 10-13.2009. Wydz. Geologii UW, Warszawa: 129-131.

Szczepanik Z., 2008. Wyniki badań dojrzałości termicznej materii organicznej na podstawie wskaźnika TAI. [W:] Malec J. (red.). Potencjał węglowodorowy utworów paleozoiku i mezozoiku północno-zachodniego obrzeżenia Gór Świętokrzyskich. Narodowe Archiwum Geologiczne PIG - PIB, Kielce.

Szczepanik Z., 2018. Wyniki badań dojrzałości termicznej materii organicznej na podstawie wskaźnika TAI. [W:] FijałkowskaMader A. (red.). Nieświń PIG 1. Profile Gtębokich Otworów Wiertniczych Państwowego Instytutu Geologicznego, 151: $146-150$.

Szczepanik Z., 2019. Dojrzałość termiczna palinomorf kambru. [W:] Szczepanik Z. (red.). Zaręby IG 2. Profile Gtębokich Otworów Wiertniczych Państwowego Instytutu Geologicznego, 155: 96-97.

Szczepanik Z., Malec J., 2001. Reżim termiczny obszaru świętokrzysko-nidziańskiego oraz pozycja paleogeograficzna Gór Świętokrzyskich w świetle badań paleozoicznej flory i fauny. Narodowe Archiwum Geologiczne PIG - PIB, Kielce.

Traverse A., 1994. Sedimentation of organic particles. Cambridge University Press, Cambridge.

Tyson R.V., 1995. Sedimentary organic matter. Chapman et Hall, London, New York, Tokyo.

Utting J., Goodarzi F., Dougherty B.J., Henderson C.M., 1989. Thermal maturity of Carboniferous and Permian rocks of the Svedrup Basin, Canadian Arctic Archipelago. Geological Survey of Canada, Paper, 89-19: 1-20.

Waksmundzka M., 1995. Wykorzystanie materiału palinologicznego do określenia stopnia metamorfizmu materii organicznej metodą TAI. Przeglad Geologiczny, 43: 107-109.

Waples D.W., 1985. Geochemistry in petroleum exploration. International Human resources Development Corporation, Boston.

Wróbel M., Kotarba M.J., Kosakowski P., 2008. Jedno- i dwuwymiarowe modelowania numeryczne procesów generowania, ekspulsji i migracji węglowodorów w utworach karbonu południowo-wschodniej części rowu lubelskiego. Geologia, 34: 171-193.

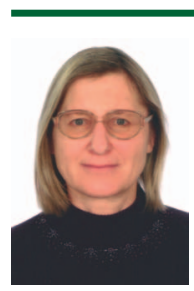

Dr Anna FIJAŁKOWSKA-MADER

Starszy specjalista

Państwowy Instytut Geologiczny - Państwowy Instytut Badawczy

Oddział Świętokrzyski im. Jana Czarnockiego

ul. Zgoda 21, 25-953 Kielce

E-mail:anna.mader@pgi.gov.pl 